\title{
Chapter 11 \\ Latin American Economic Crises \\ and Populist Bids: Argentina, Brazil and Mexico
}

\author{
Maria Antonieta Del Tedesco Lins
}

\begin{abstract}
Through a comparative case study analysis, the chapter seeks to retrace the recent history of Argentina, Brazil and Mexico in dealing with economic crises. Despite their different institutional arrangements and macroeconomic trajectories, the comparison shows that domestic concerns were the main drivers of economic policies. Particularly regarding each country's approaches to exchange markets and capital controls - here called financial policy - the chapter evaluates the extent to which they contradict international perceptions and even the International Monetary Fund's (IMF's) stance on financial regulation and the management of capital flows. A close relationship between domestic political demands and the design of economic policy indicated that even in the face of some similarity between the challenges posed to the three countries and more than responses to changes in the world economy and the quest to keep these economies integrated, economic policy aimed to accommodate internal political pressures.
\end{abstract}

\section{Introduction}

Crises are a common feature to barely all analyses of Latin American economic history. The 1980s' debt crisis besides blocking the region's access to international financial markets led to economic stagnation, hiking inflation and poverty increase. Since the late 1980s, debt renegotiation, programs of macroeconomic adjustment and liberalization policies opened a new phase for the region. Hand in hand with the economic transition was the political one. Democracy building on the onset of military regimes and the reign of long-lasting ruling parties was a remarkable challenge to be conciliated with macroeconomic and institutional reforms. Argentina, Brazil and Mexico, the three largest economies in the region, shared this experience but, although having adopted several similar policies in their economic reform programs

\footnotetext{
M. A. D. T. Lins ( $\square)$

Universidade de São Paulo - Institute of International Relations, São Paulo, SP, Brazil

e-mail: madtlins@usp.br
} 
since the 1990s, they cannot be considered resembling fragments of a common model. Their respective political idiosyncrasies have led to quite diverse economic policy arrangements ever since. The chapter recovers the economic and political trajectories of these three countries since the early 1990s, against the backdrop of the 1980s' debt crisis, its impacts and the ensuing liberalization reforms. Financial and exchange rate policies are in the spotlight to analyze the countries' performances throughout the different crises and their financial insertion in the world economy. In all three cases, monetary, exchange rate and financial openness policies were instrumental in determining both the intensity of each country's financial integration and the degree of vulnerability to which they were subject when the global financial crisis hit. It is argued that despite their very diverse political trajectories, flirts with populism inspired economic policy in critical moments in the three cases.

The 1980s' Latin American foreign debt crisis and the ensuing lost decade reflect the previous period during which the presence of military dictatorships in several countries of the region is key to understanding economic policy focused on maintaining high rates of output growth, despite rising inflation, especially in Argentina and Brazil. High liquidity in international financial markets in the run-up to the oil crisis granted these countries the access to credit from abroad at floating and initially low interest rates, allowing them to postpone necessary reforms and preserve growth. The fight for economic normalization in Latin American countries following debt renegotiation in the late 1980s was uneven and consisted of two big challenges: macroeconomic stabilization and long delayed structural reforms as necessary conditions to resume growth. Most of the reforms were inspired by what was labeled the Washington Consensus, a set of liberalizing measures which, in the three cases here, were coupled with the adoption of pegged currency exchange regimes. These profound macroeconomic transformations both led the three countries to a new phase of increasing integration into the world economy and gradually triggered the financial crises that followed. However, the intensity of their crises in 1994 (Mexico), 1998-1999 (Brazil) and 2001-2002 (Argentina) was quite diverse and proportional to the commitment to the hard-pegged exchange rate regime of each one (Wiesner 2008; Kaminsky et al. 2009).

The literature on Latin American financial systems and central bank reform tends to emphasize international actors and pressures as key determinants of policy change. In contrast, and furthering the argument that economic policy had pinches of populist inspirations in a number of episodes of recent history, this chapter argues that domestic concerns were the main drivers of financial policy making after the 2008 crisis even in countries with different institutional arrangements and macroeconomic trajectories such as Brazil, Mexico and Argentina. Through a comparative case study analysis, the chapter seeks to retrace the three countries' approaches to exchange markets and capital controls and evaluate to which extent they contradict international perceptions and even the International Monetary Fund's (IMF's) stance on financial regulation and the management of capital flows. Populist economic policies can be traced despite a number of government shifts after 
democratization-broadly situated in the late 1980s. ${ }^{1}$ As the following discussion intends to put, populist temptations prevailed mostly in Argentina and Brazil. ${ }^{2}$

The text is divided into three main sections besides this introduction and the concluding remarks. Next section recovers in broad lines the Latin American debt crisis, distinguishing each country's political situation before 1982, thereafter and leading to the liberalizing reforms of the 1990s. The third section focuses on the three nations' respective financial crises during the 1990s and 2000s and their political and economic consequences. The fourth section scrutinizes the reactions of Argentina, Brazil and Mexico to the 2008 global financial crisis, a period during which three very distinct political orientations were in place in each of the three countries.

\section{From Over-Indebtedness to Economic Collapse: Latin American Saga}

The literature on the legendary Latin American debt crisis usually points to the national state as the main source of instability (e.g. Skidmore and Smith 2005). Bresser-Pereira (1992) summarizes the different positions on the Latin American crisis and groups them into two explanatory theories from which arise reform proposals: the neoliberal and the fiscal crisis approaches. The neoliberal view, giving birth to the so-called Washington Consensus, was the international financial bodies' common view and enjoyed strong influence over Latin American leaders. The heterodox approach stressed the state's inability to follow previous development policy. The neoliberal approach identifies two major causes for the crisis in Latin America: the extreme growth of the state manifested by too much intervention in the economy with emphasis on protectionism; and the economic populism that would prevent the state from controlling social demands in accordance with the sanitation needs of public finances. Following this logic, the crisis must be initially countered by a rebalancing of public accounts and stabilization before a market-oriented growth policy is launched, where the state would have its space reduced. The return of the development process would be a logical consequence of adjustment.

\footnotetext{
${ }^{1}$ Latin America experienced new forms of populism at the turn of the twenty-first century, with the rise to power of governments that made up the so-called 'Pink Tide' - a period characterized by the presence of several center-left governments in the 1990s and 2000. But right-wing populism would still come back in more recent versions, as the world has been experiencing a surge of these "not so new populisms." They arise as a reaction to the deepening globalization and its effects on national production, population flows and capital movements, among other social and economic transformations, but their emergence do not replace the so-called "old populisms." This chapter is aligned with the definitions of populism presented by Rodrik (2018) and Grigera (2017).

${ }^{2} \mathrm{~A}$ thorough analysis of the economic policy shifts in Mexico and Brazil after their elections in 2018 and 2019 goes beyond the chapter's time frame.
} 
The approach to the fiscal crisis suggests that the loss of the state's ability to save and invest, which stems from stabilization programs, precludes it from resuming its control of long-term development policies. The shift from public to private investment is not automatic, and the economy stagnates until the private sector sees no greater interest in investing. Government deficit as a structural problem leads to a broader crisis of the state coupled with the loss of credibility of governments in power as the crisis deepens. Despite the direction of causality between the state crisis and adjustment policies being reversed among them, arguments from both approaches can be used to understand the crises that followed.

Mexico was not under military rule in the 1970s and 1980s but faced a crisis of a similar kind to the other two countries. With the exception of Colombia, all Latin American countries that took massive credit during the 1970s went bankrupt in the 1980s (Damill et al. 2005, p. 189). In the early 1980s, falling international oil prices, rising US interest rates and the high level of accumulated foreign debt from the previous period led the Mexican economy to extreme external vulnerability. It was the dawn of insolvency crisis. During Miguel de la Madrid's government (1982-1988), an intense debate about the orientation of economic policy took place confronting structuralist positions with groups clearly in favor of liberal reforms (Maxfield 1992). According to Santín Quirós (2001), the government's political support coalition was mostly "financial." The nationalization of the banking sector carried out by the Mexican government in 1982 was conceived against a crisis backdrop and was defined within an unambiguously liberal inspiration, from the appointment of the president de la Madrid's economic team, through a design of reform that was frankly favorable to the financial sector, both regarding the amounts paid by the state for the nationalized financial institutions and the main framework to redress the national financial system (Santín Quirós 2001).

In Brazil, the 1974 presidential transition had a broader political significance, as a group with a project of political distension who would lead to the gradual opening of the regime came to power. Economic policy was executed considering this political circumstance for the new government could not achieve a worse economic performance than those obtained by its predecessors. The world economy's cyclical reversal forced Brazilian policy makers to face different problems: conforming to a new international reality; adjusting domestic macroeconomic situation, given that inflation was accelerating; and maintaining high growth rates. With the outbreak of the Mexican crisis in 1982, it was no longer possible for the military to postpone a request for IMF financial aid. This point in time can officially be considered the beginning of Brazilian debt crisis (Garriga and Lins 2014, p. 60). What followed was a struggle for macroeconomic stability amid a complete imbalance in external accounts and a long series of failed economic plans under the IMF's agenda. This process generated a decade and a few years lost.

The 1980s began with Argentina facing serious deadlocks. The retreat of military regime was marked by a hard defeat in the Malvinas war against Britain. Election in 1982 brought a civilian back to power, Raúl Alfonsin (1983-1989), with an expectation that his mandate could confront major problems: inflation rates of over $200 \%$ a year as early as 1982, rising to $400 \%$ the following year, and the undisputable 
inaptitude to manage and repay private foreign debt. The next inescapable step would be to turn to the IMF and face structural adjustment policies as a conditionality of obtaining a loan (Skidmore and Smith 2005). Referring not only to the 1980s' chronic Argentine indebtment but also to the succeeding crisis of 2002, Damill et al. (2005) state: "for around three decades external debt was almost constantly one of the main issues of economic policy."

Hence, those who agree with the diagnosis of the fiscal crisis see the Latin American debt crisis as the major consequence of the financing model adopted as economic stimulus in the previous period, which resulted in excessive indebtedness and also prolonged maintenance of the import substitution policy (Griffith-Jones and Sunkel 1986, inter alia). Structural problems persisted throughout the 1980s, despite all attempts to adjust. The crises' fiscal feature translated into public accounts deficits but also brought financial and political components to all those crises.

Adjustment programs have not been effective in rebalancing external accounts and controlling inflation nor have they ensured output growth that would lift countries out of crisis with even the IMF policies not being strictly followed by governments. Argentina and Brazil have reached hyperinflation, which has profoundly deteriorated personal income, particularly in the lower classes. Although not attaining Argentine and Brazilian levels, inflation in Mexico also remained very high, particularly after 1982. Thereafter, overcoming the 1980s' crises should be achieved by combining macroeconomic stability and the pursuit of greater international integration of countries, which was accomplished in the following decade.

\section{Liberalization Policies Cum Financial Crises in the 1980s and 1990s}

From debt renegotiation and restructuring, Latin American countries have been implementing reforms in their economic policy framework. The rhythm and intensity of the reforms were defined by each country's political trajectory and the readjustment needs. Regarding financial liberalization, quite different patterns were taken. Net inflows of foreign capital in emerging markets resumed and increased substantially in a short period of time since 1990 .

Several similarities that marked the three largest Latin American economies during the 1980s and through part of the 1990s seem to vanish as Argentina, Brazil and Mexico delineated distinct economic policy paths since the late 2000s. The unfolding of the late 1990s-early 2000s and 2008-2009 crises was quite particular in each one of the three countries due to both their general economic conditions and the political choices that have been made during and after the crises. Generally

\footnotetext{
${ }^{3}$ In the original: "Por cerca de tres décadas la deuda externa fue casi ininterrumpidamente una de las preocupaciones centrales de la politica econômica." (Damill et al. 2005: 187).
} 
speaking, since 2007 Argentina has adopted a model of state-led economic strategy quite diverse than both Brazil and Mexico economic models. While Argentina was taken away from the international financial markets and was implementing an increasingly protectionist and interventionist economic policy, both Brazil and, to a greater extent, Mexico maintained a stable macroeconomic pattern, at least until late 2010s, in the Brazilian case.

\section{Mexico}

Mexico began to open to global financial markets as early as the late 1980s, under the IMF structural adjustment programs. The Mexican authorities have since launched financial reforms that spanned the domestic financial system and opened the capital account. In addition, interest rates were liberalized, selective credit policies were eliminated and a system of multiple banks was established until the privatization of banks in the early 1990s. The opening of the capital account allowed the presence of foreign investors in public securities markets and capital markets and gave Mexican companies the opportunity to issue bonds in foreign markets. The inflow of foreign direct investment was stimulated by an institutional reform in 1993. The Mexican case presents some peculiar features. The banking system was nationalized during the 1980 s amidst the debt crisis. Financial institutions' reprivatization and the financial reforms led by the Salinas government (1988-1994) were clearly motivated by neoliberal ideas and can be seen as a coordinated attempt to build legitimacy and political support for the government (Santín Quirós 2001; Sandoval 2011).

Similarly to Argentina and Brazil, stabilization centered around monetary and exchange rate policies since the 1980s. The external financing constraint and fiscal problems imposed limits to growth, and inflation control became the top priority. A crucial reform in conducting monetary policy was introduced in 1993 via constitutional amendments. This change effectively institutionalized the operational autonomy of the Mexican Central Bank as constitutional independence. Priority was given to the stabilization of the Mexican currency's purchasing power. However, the heightened confidence in the monetary authority was not strong enough to prevent the currency crisis of 1994.

Since 1992, the Mexican currency was clearly over-valued. Along with a deteriorating balance of payments, political instability set off a speculative attack against the peso. The rigidity of the adjustment mechanism that had been adopted made adjustment in the face of market pressures a difficult proposition. When new Zedillo government (1994-2000) tried to change the mechanism of bands, performing a more or less controlled devaluation, the decision set off a wave of panic. Confidence in the Mexican economy deteriorated even further with an intense capital flight (Garriga and Lins 2014). The Mexican crisis was an important but not yet the final chapter in the epic of fixed exchange rate regimes in Latin America. This concurred 
with the implementation of the Real Plan in Brazil and with an extremely prosperous-albeit unsustainable - time in Argentina's convertibility regime.

\section{Argentina}

In Argentina, financial openness was a key element of the Convertibility Plan adopted in 1991. To protect against inflation, the economy had been steadily "dollarized" since mid-1980. The adoption of the currency board and, therefore, the establishment of legal tender status for the dollar led to total freedom for capital flows in the country. Besides the previous rules facilitating transactions in dollars, the Convertibility Law allowed the establishment of contracts in any foreign currency. Deregulation of the capital account in 1991 complemented this move to convertibility (Klagsbrunn 2010; Damill et al. 2011).

The literature describes two major growth episodes since the 1990s. The first period, from 1992 to 1998 , may be considered as the apex of the convertibility model. The economy was organized around market institutions, and modernizing reforms were introduced. However, contrarily to the success obtained by the 1991 monetary reform, the process of fiscal reordering process was much less evident. The long persistence of the exchange regime, high interest rates and insufficient financial development would be the explosive ingredients that, in addition to the international financial turmoils, would detonate the crisis (Crisitini 2008, Labaqui 2014; Damill and Frenkel 2012, 2013; Damill et al. 2011; Fanelli 2013). In January 2002, the country lost $50 \%$ of its foreign reserves - that occurred even with the establishment of the corralito, limiting banking withdrawals - and the currency lost $40 \%$ of its value in the month the crisis began and $265 \%$ in the following 6 months (Kaminsky et al. 2009).

After the 2001-2002 crisis, Argentina witnessed episodes of intense growth. Policy patterns in Argentina, however, changed over time as state interventionism became more prominent under President Cristina Kirchner's consecutive mandates (Labaqui 2012). Government control spread to all spheres of economic life, including increasingly less reliable official statistics.

Argentina benefited from the world economy's prosperity period until 2007, particularly due to the rising price of commodities, which gave the country some comfort in the external accounts to set up the guidelines of economic policy in accordance with domestic policy priorities. However, and as expected, Argentina has been almost completely excluded from the international financial markets since 2001. Despite broad acceptance among Argentina's creditors of the 2005 and 2010 restructuring offers, a group of holdout creditors successfully litigating against Argentina in US courts has effectively posed an obstacle to the country's ability to issue debt abroad. The risk is that these disgruntled creditors will cease any assets distributed overseas as part of their standing legal claims for repayment. As a result, since the mid-2000s, Argentina has engaged in "creative" and interventionist funding schemes such as the nationalization of pension funds (Labaqui 2014). 


\section{Brazil}

The Brazilian liberalization process was discreet compared to those of Mexico and particularly Argentina. Brazilian authorities began in the late 1980s-1990s opening different segments of financial markets (currency, fixed income and equity) to the entry of foreign capital. The banking system was not completely opened and transactions in other currencies were never permitted (Gottschalk and Sodré 2008; Freitas and Prates 2001). With monetary stabilization, a profound restructuring of markets took place, leading to the disappearance of several institutions and the promotion of higher market concentration. ${ }^{4}$ The whole process led to a decrease in the number of public banks given the privatization of state banks and the strengthening of federal banks that remained in operation. The entry of large foreign banks and a greater concentration among domestic private ones drove to more competition amid larger financial institutions. These moves to reorganize the financial system, coupled with fairly rigid financial supervision and a relatively low degree of openness, ensured that the amount of international transactions of the financial system did not set up high vulnerability and dependence on external funds.

Either to attract portfolio investments in periods of current account deficit or to keep the process of reserve accumulation at times of international liquidity, high interest rates were a constant element of Brazilian economic policy, both during the pegged exchange regime and when flotation was embraced. Between 2003 and 2007, Brazil witnessed increasing portfolio capital inflows (see Fig. 11.1).

Brazil never granted de jure autonomy or independence for its central bank. After modifying the exchange regime and adopting the inflation targeting system in 1999, the Brazilian central bank worked "autonomously" for about 10 years. This can be explained by the priority given to inflation control due to its huge political and economic importance in a context of benign global economic conditions.

\section{Policy Responses to the 2008 Crisis}

On the eve of the 2008 global crisis, Argentina was experiencing twin surpluses (fiscal and current account) since its post-2002 resurrection. The economy was boosted by both the commodities boom and the new type of macroeconomic populism ${ }^{5}$

\footnotetext{
${ }^{4}$ Price stabilization after 1994 led to a deep reduction in banks' earnings from inflation and indexation praxis. Large private banks such as Econômico (August 1995) and Nacional (November 1995) went bankrupt. State government banks were privatized, and federal banks were recapitalized and reformed (Mettenheim 2010).

${ }^{5}$ The idea and paradigm of "macroeconomic populism" were defined by Dornbusch and Edwards (1992), and has been widely applied to economic policy experiences in Latin America. As they define: "Macroeconomic populism is a policy perspective on economic management that emphasizes economic growth and income redistribution and deemphasizes the risks of inflation and deficit finance, external constraints and the reaction of economic agents to aggressive non-market policies.” (op.cit, 247).
} 


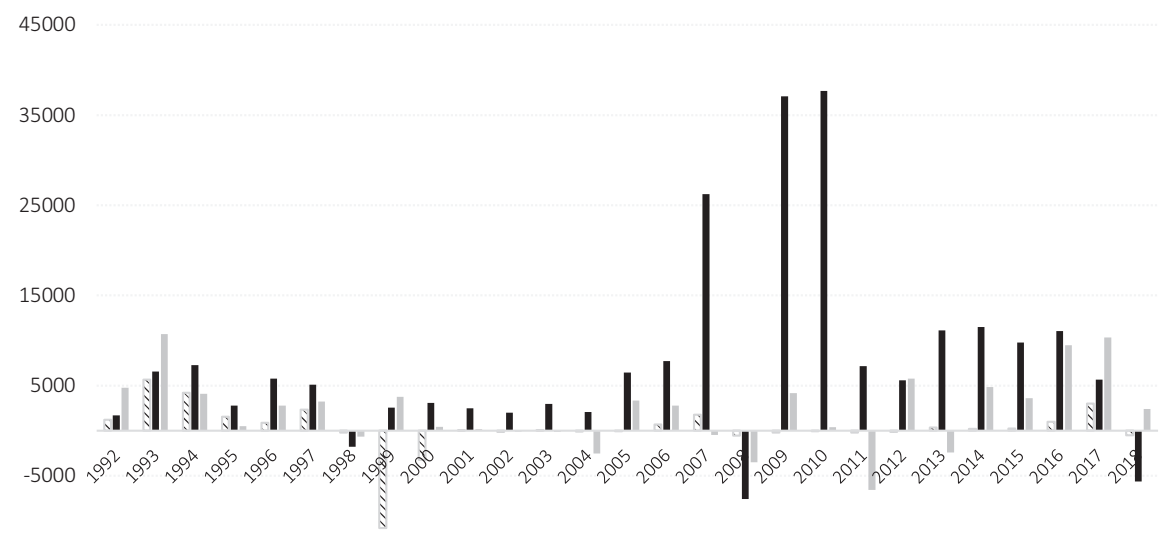

$-15000$

s Argentina $\square$ Brazil $\square$ Mexico

Fig. 11.1 Portfolio equity net flows, current US\$ millions. (Source: World Bank)

established since 2007 (Labaqui 2014; Damill and Frenkel 2013; Fanelli 2013). The Brazilian economy too was undergoing a prosperous phase when the crisis deepened in 2008. After a few years of fiscal discipline that restored international credibility and helped the country regain a certain level of stability, Brazil was in the midst of an expansionary turn in economic policy, characterized by measures to stimulate domestic consumption and investment in specific sectors. Therefore, countercyclical policies marked the expansion and specialization of some policies already in place, such as credit expansion by state-owned financial institutions and tax exemptions to particular industrial sectors related to domestic consumption or potential exporters (Wise and Lins 2015).

In contrast, Mexico was severely hit by the crisis, a temporary reversal of an upward growth trend from 2002 to 2007. This was a result of higher oil prices, exports to the USA, larger remittance inflows and consequent currency appreciation. All contributed to over expenditure before the 2008 global crisis. The proximity to the US economy, that had fueled Mexican exports, meant that the effects of the crisis were deeper, notably through currency depreciation. However, Mexico rebounded relatively quickly from the initial shock. According to the IMF's Assessment on the Mexican financial system, the commitment to the inflation targeting and floating exchange rate scheme, combined with the effort to maintain fiscal discipline, were key factors explaining Mexican rebound since 2010 (IMF 2012). Financial sector restructuring after 1995, its lower external exposure and a quite moderate central bank reaction to the crisis were peculiar characteristics of the Mexican case (Esquivel 2015).

Despite their different reactions to the crisis, the three countries were capable of holding high amounts of foreign reserves in absolute terms. Yet, when considering the rate international reserves to GDP, Argentina's figures declined significantly since 2007 to recover after 2015 (Fig. 11.2). Capital flight from Argentina started in 


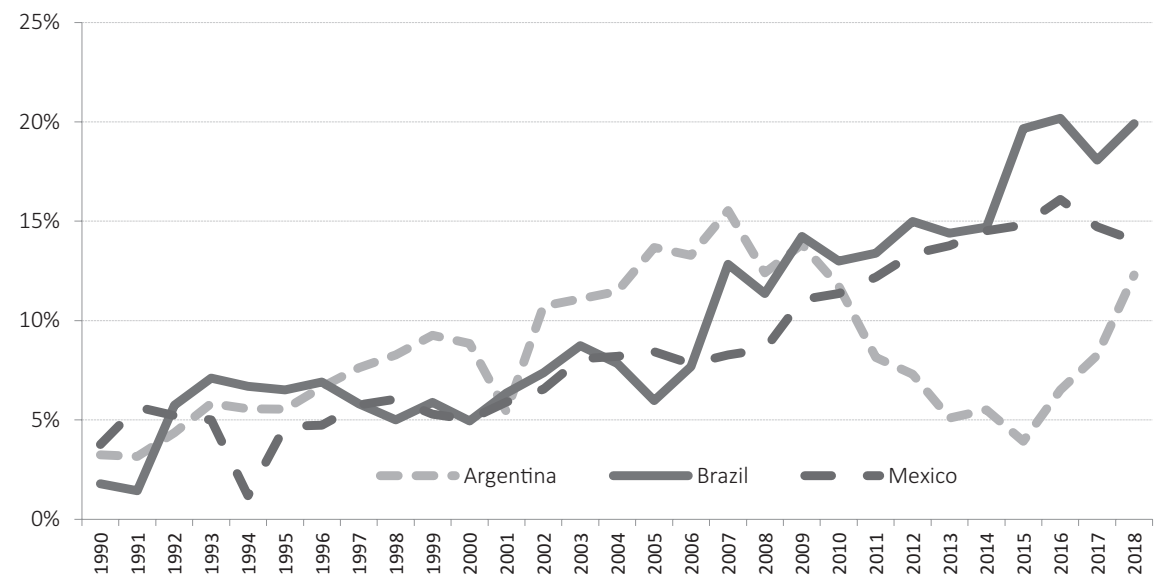

Fig. 11.2 Foreign Reserves/GDP Ratio, \%. (Source: World Bank, author's calculation)

early 2007 precisely when underestimation of inflation rates became a public and ongoing practice, and from then on, the credibility of the economic policy went steadily declining. The falling prices of the country's government bonds in international currency and the higher spreads measured by markets relatively to non-risk assets illustrate the process (Damill and Frenkel 2012).

Argentina, Brazil and Mexico experienced very unstable portfolio investment inflows after the crisis. Besides the fluctuations in international markets, the ability to attract foreign capital was extremely uneven among the three countries, as Fig. 11.1 depicts. Since late 2011, large emerging economies showed a trend to growth at a slower path. Shifts in industrialized countries' monetary policies, and consequently higher interest rates in safe markets, brought less capital to large emerging economies than before. At the same time, these economies started managing capital account more closely, in order to protect themselves and/or with other policy goals (Gallagher and Tian 2017). Brazil has been a pioneer in using taxes to control capital outflows. Mexico, on the contrary, has been rewarded by risk agencies for its conservative approach to economic policy. Shortly, in different extents, emerging economies implemented new policies or reformed old ones, bringing new facts to the markets and new configurations to their own policy frameworks.

\section{Policy Changes}

Argentina, Brazil and Mexico took advantage of long and pronounced increases in commodity prices during the 2000s. Regarding financial flows, Brazil and Mexico were able to attract capital and issue bonds in external markets, when considering the various differences among these assets. Argentina was gradually isolated from the international financial markets both by the lost credibility of government bonds 
and by the constraints imposed on the private sector access to external credit markets.

Since 2007 Argentina had been experiencing stronger state intervention which also included government intervention at the federal statistics institute, the nationalization of private pension funds and other previously privatized corporations, ${ }^{6} \mathrm{a}$ conflict between the administration and the central bank, and a confrontation with the agriculture sector (Labaqui 2012; Damill and Frenkel 2013). ${ }^{7}$ These facts substantially deteriorated the risk perception of international markets and contributed, along with the crisis, to the severe capital outflows the country experienced since late 2007, whose adverse impacts on the balance of payments were offset by the benign effects of international commodity prices. Labaqui (2012) describes how President Cristina Fernández de Kirchner tried to regain the confidence of international financial markets', and thus reduce Argentine bonds' spread, by normalizing external debt payments (albeit not engaging with holdout creditors). She then proceeded to try to convince skeptical observers and investors about the economic stability of the intra public sector financing scheme by using resources that originated from the nationalized pension funds to pump up national reserves. From there on, Argentina experienced a sequence of discretionary policy changes and institutional uncertainty.

In Brazil, the political scenario was mainly favorable to the government in 2008-2009. President Lula was in the middle of his second term and, despite major corruption scandals involving his party and important political leaders connected to him, popular approval of the government remained high. Gains that had been achieved by the lowest income groups provided an important source of political support to the government, as well as the image of Brazil as an emerging power. The worsening economic situation after the crisis was hence not a politically acceptable alternative for the country.

In fact, since the beginning of Lula's first term, a particular group dissatisfied with the direction of economic policy within the president's Workers' Party had been criticizing its "neoliberal" features. Once macroeconomic stability was achieved, for this group, it was time to change policy goals and directions. Progrowth measures should be combined with stability in normal times. When the crisis came, pro-growth measures were already in place and, while they were being implemented, a broader set of new measures was created, as a program intended to

\footnotetext{
${ }^{6}$ Examples are the airline Aerolineas Argentinas and the oil company YPF.

7 "Enfoquemos ahora en mayor detalle el canal financiero. Los cambios en el contexto financiero global se reflejaron principalmente en una variable: las salidas de capitales privados. La denominada "huida hacia la calidad" afectó a muchas economías en desarrollo, particularmente en el último trimestre de 2008. En el caso argentino, varias fuentes internas de incertidumbre se adicionaron al impacto de los shocks externos negativos. Cuatro factores se destacan como los más importantes. Ya hemos comentado la manipulación de las estadísticas oficiales de inflación desde comienzos de 2007 y el conflicto entre el gobierno nacional y los productores agropecuarios. Se agregarían luego la nacionalización del sistema privado de pensiones a fines de 2008 y, finalmente, el conflicto relacionado con la utilización de reservas de divisas del Banco Central para hacer frente al servicio de la deuda pública, en 2009.” Damilll and Frenkel (2013), p. 18.
} 
be a new industrial policy, which increased tax benefits to selected sectors and incentives to producers with export potential. ${ }^{8}$ With the transition from Lula's to President Dilma Rousseff's administration, there was an important shift in the economic team. In light of the poor economic performance since 2011, state interventionism gained more ground to the detriment of the commitment to macroeconomic stability. The relationship between the executive and the central bank took on a more "intimate tone," largely at the expense of the monetary authority's credibility. Rousseff's first mandate favored a long waited - by the developmentalist group in PT-shift in the relationship between the central bank and the Finance ministry. Under Lula, the arm wrestling between the two institutions has mostly been won by the central bank. Its governor Henrique Meirelles and his team enjoyed a de facto operational autonomy and kept the commitment to the inflation target.

Mexico, despite the various previous internal reforms and the pro-market approach of its policy framework, as mentioned above, was far from shielded from the adverse impacts of the crisis. Mexican political scene is much more complicated than the relatively short list of presidents in recent years might lead one to believe. Democracy is relatively new and younger than that of Argentina and Brazil, considering the transition of power from the previously hegemonic PRI to the PAN with the election of Vicente Fox in 1999. This event broke the cycle of over 70 years of PRI administrations. ${ }^{9}$ However, 12 years of PAN administrations did not bring about fundamental change despite the party's more conservative (right-wing) platform compared to that embraced by the PRI.

Indeed, during most of the twentieth century, Mexico experienced a very particular political regime, which some political scientists have called "exceptional." While many Latin American countries were plagued by political instability, coups and military crises of governance, the Mexican political system was largely stable, while dominated by the PRI. These 70 years of authoritarianism and clientelism had effects on the practice of politics that the 12 years of the PAN administrations failed to overcome. When the global crisis erupted, Mexico was highly dependent on the US economy and torn by violence from confrontations related to drug trafficking. In December 2012, Enrique Peña Nieto returned the PRI back to power, bringing with him a "well trained" team of technocrats to the Finance Ministry and central bank, most of whom had been educated in the USA.$^{10}$ This was a totally different approach to Mexico's economic policy design than those found in Argentina and Brazil at that time.

To sum up, Brazil, Argentina and Mexico presented very different political scenarios when dealing with the impact of the 2008 crisis. These differences are relevant in regard to both the general political orientation of the parties in power and the

\footnotetext{
${ }^{8}$ Plano Brasil Maior (Greater Brazil Plan), launched in August 2011. (http://www.brasilmaior. mdic.gov.br/inicio).

${ }^{9}$ Partido Acción Nacional - PAN (in Spanish), National Action Party and Partido Revolucionario Institucional - PRI, Institutional Revolutionary Party (in Spanish).

${ }^{10}$ See The man from MIT. The Economist, March 22, 2014.
} 
more immediate motivations of economic policy in the post-critical phase of the global crisis.

\section{Conclusion}

Through a comparative case analysis study, this chapter sought to understand how the three largest Latin American economies dealt with their economic crises in the past four decades. The argument was that, despite the close relations maintained by these countries with multilateral organizations such as the IMF, and the intense financial integration process that marked the period and brought profound changes to the region, domestic political choices prevailed over possible international pressures on crisis management and policy making.

Since 2000, among the three countries, Argentina suffered the most instability and output volatility as a result of the crises. Its own crisis in 2001-2002, when the macroeconomic framework broke and strong uncertainty, recession and inflation increased, and during the attempt to stabilize and reform made by Mauricio Macri government (2015-2019). In Brazil, the severe crisis that deepened from 2014precipitated by the Rousseff's government "growth at any cost" policy-was used as a pretext for conservative forces in Congress to engender a parliamentary coup that led to the impeachment of the president, and even more instability. Mexico maintained a more disciplined economic policy, anchored in its institutions, such as the independent central bank. But that was not enough to prevent a growing social discontent that led to the election of a left-wing populist proposal presented by Antonio Manuel López Obrador in 2017.

In the three cases, a close relationship was observed between domestic political demands and the design of economic policy. Although there were similarities between the challenges faced by the three countries, such as the need to respond to changes/shifts in the world economy, each country's economic policy sought, above all, to accommodate internal political pressures.

\section{References}

Bresser-Pereira, L. C. (1992). A crise do Estado. Ensaios sobre a economia brasileira. São Paulo: Nobel.

Crisitini, M. (2008). Argentina. In P. Fischer-Bollin \& E. Saavedra (Eds.), Crecimiento y progreso social en América Latina (pp. 17-46). Rio de Janeiro: Konrad Adenauer Stiftung.

Damill, M. \& Frenkel, R. (2012). Macroeconomic policies, growth, employment, and inequality in Latin America. UNU-WIDER Working Paper No. 2012/23.

Damill, M., \& Frenkel, R. (2013). La economía argentina bajo los Kirchner: Una historia de dos lustros. Instituto de Transparencia Financiera-ITF. Documentos técnicos, 1-41.

Damill, M., Frenkel, R., \& Rapetti, M. (2005). La deuda argentina: Historia, default y reestructuración. Desarrollo Económico, 45(178), julio-setiembre, 187-233. 
Damill, M., Frenkel, R., \& Simpson, L. (2011). Regulaciones financieras y macroeconomía: La experiencia paradigmática de la Argentina en los años noventa. Desarrollo Económico, 50(200), 547-578. www.jstor.org/stable/41408181.

Dornbusch, R., \& Edwards, S. (1992). The macroeconomics of populism. In R. Dornbusch, \& S. Edwards (Eds.), The macroeconomics of populism in Latin America (pp. 7-13). National Bureau of Economic Research conference. Chicago: The University of Chicago Press.

Esquivel, G. (2015). Mexico's recovery from the global financial crisis. In C. Wise, L. E. Armijo, \& S. N. Katada (Eds.), Unexpected outcomes: How emerging markets survived the global financial crisis. Washington, DC: Brookings Institution Press.

Fanelli, J. M. (2013). Mirando el 2014 en Argentina: ¿dónde está el piloto? Observatorio Económico de la Red Mercosur, Diciembre. Available at: http:// www.oered.org/index.php?option $=$ com_content $\&$ view $=$ article $\&$ id $=252 \% 3 \mathrm{Amira}$ ndo-el-2014-en-argentina-idonde-esta-el-piloto-\&lang=es

Freitas, M. C. \& Prates, D. M. (2001). A abertura financeira no governo FHC: impactos e consequências. Economia e Sociedade, Campinas, 17, Dezembro, 81-111.

Gallagher, K. P., \& Tian, Y. (2017). Regulating capital flows in emerging markets: The IMF and the global financial crisis. Review of Development Finance, 7, 95-106.

Garriga, A. C., \& Lins, M. A. D. T. (2014). El camino hacia la estabilidad: Treinta años de la moneda en Brasil y en México. In M. M. Sousa \& C. Maldonado (Eds.), En Busca del Desarrollo: Una Comparación de las Estrategias de Desarrollo de Brasil y México (pp. 55-103). México: CIDE.

Gottschalk, R., \& Sodré, C. A. (2008). The liberalization of capital outflows in Brazil, India and South Africa since the early 1990s. In P. Arestis \& L. F. Paula (Eds.), Financial liberalization and economic performance in emerging countries. New York: Palgrave Macmillan.

Griffith-Jones, S. \& Sunkel, O. (1986). Debt and development crises in Latin America: The end of an illusion. New York: Oxford University Press.

Grigera, J. (2017). Populism in Latin America: Old and new populisms in Argentina and Brazil. International Political Science Review, 38(4), 441-455.

IMF (2012). Mexico Financial System Stability Assessment. IMF Country Report No. 12/65. Available at: https://www.imf.org/en/Publications/CR/Issues/2016/12/31/ Mexico-Financial-System-Stability-Assessment-25810.

Kaminsky, G., Mati, A., \& Choueiri, N. (2009). Thirty years of currency crises in Argentina: External shocks or domestic fragility? Economía Journal, The Latin American and Caribbean Economic Association - LACEA, O(Fall 2009), 81-123, August.

Klagsbrunn, V. (2010). Brazil and Argentina in the global financial system: Contrasting approaches to development and foreign debt. In G. R. D. Underhill, J. Blom, \& D. Mügge (Eds.), Global financial integration thirty years on: From reform to crisis. Cambridge: Cambridge University Press.

Labaqui, I. (2012). Living with our own means: The role of financial policy in the Nestor and Cristina Fernandez de Kirchner Administrations. Paper prepared for the XXX International Congress of the Latin American Studies Association (LASA), San Francisco, May.

Labaqui, I. (2014). Who's afraid of reversing neoliberal reforms? Financial statecraft in Argentina and Venezuela. In L. E. Armijo \& S. N. Katada (Eds.), The financial statecraft of emerging powers. Shield and sword in Asia and Latin America (pp. 21-46). New York: Palgrave Macmillan.

Maxfield, S. (1992). The international political economy of bank nationalization: Mexico in comparative perspective. Latin American Research Review, 27(1), 75-103. Retrieved 20 Feb 2019, from www.jstor.org/stable/2503718.

Mettenheim, K. (2010). Federal banking in Brazil: Policies and competitive advantages. London: Pickering and Chatto.

Rodrik, D. (2018). Populism and the economics of globalization. Journal of International Business Policy, 1(1), 12-33. https://doi.org/10.1057/s42214-018-0001-4.

Sandoval, I. E. (2011). Crisis, rentismo y intervencionismo neoliberal en La banca: México (1982-1999). México: Centro de Estudios Espinosa Yglesias, A.C. 
Santín Quirós, O. (2001). The political economy of Mexico's financial reform. Basingstoke: Ashgate.

Skidmore, T., \& Smith, P. H. (2005). Modern Latin America (6th ed.). New York: Oxford University Press.

Wiesner, E. (2008). The political economy of macroeconomic policy reform in Latin America: The distributive and institutional context. Northampton: Edward Elgar Publishing.

Wise, C., \& Lins, M. A. D. T. (2015). Macro-prudence versus macro-profligacy-Brazil, Argentina and the global financial crisis. In C. Wise, L. E. Armijo, \& S. N. Katada (Eds.), Unexpected outcomes: How emerging markets survived the global financial crisis (pp. 148-180). Washington, DC: Brookings Institution Press.

Open Access This chapter is licensed under the terms of the Creative Commons Attribution 4.0 International License (http://creativecommons.org/licenses/by/4.0/), which permits use, sharing, adaptation, distribution and reproduction in any medium or format, as long as you give appropriate credit to the original author(s) and the source, provide a link to the Creative Commons license and indicate if changes were made.

The images or other third party material in this chapter are included in the chapter's Creative Commons license, unless indicated otherwise in a credit line to the material. If material is not included in the chapter's Creative Commons license and your intended use is not permitted by statutory regulation or exceeds the permitted use, you will need to obtain permission directly from the copyright holder. 